\title{
Does ruminal retention time affect leafy spurge seed of varying maturity?
}

\author{
BRET E. OLSON AND ROSEANN T. WALLANDER
}

Authors are Professor and Research Associate, Department of Animal and Range Sciences, Montana State University, Bozeman, Mont. 59717-2900.

\begin{abstract}
Grazers ingest seeds of invasive forbs and may contribute to their spread by depositing viable seeds in uninfested areas. Some mature seed pass through the gastrointestinal (GI) tract of ruminants, but grazers consume flowerheads of invasive species from anthesis to dehiscence. We collected seed from the Eurasian leafy spurge (Euphorbia esula L.) at 3 stages of maturity (soft dough, hard dough, mature). With seed collected from these different stages, our objectives were to determine effects of 1) rate of passage through the GI tract of sheep on leafy spurge seed recovery, germinabilty and viability, 2) residence time in sheep rumen on seed germinability and viability, and 3 ) acid pepsin digestion, simulating the lower GI tract, on seed germinability and viability after different residence times in the rumen. More seed from the later stages of maturity were recovered in the manure. The greatest number of seed recovered only represented $3.9 \%$ of the number of ingested seed. Few seeds were recovered after day 4 . Soft dough seed in manure would not germinate and was not viable, whereas hard dough and mature seed collected from manure during the first $\mathbf{4}$ day were viable. Pepsin had a slight effect on the number of mature seed recovered, but eliminated viability of recovered seed. Viability of non-pepsin treated seed from the hard dough and mature stages declined with greater residence time in the rumen. Thus, managers should be aware that livestock ingesting hard dough as well as mature seed may be dispersing viable weed seed.
\end{abstract}

Key Words: weed, Euphorbia esula, rumen, sheep

Leafy spurge (Euphorbia esula L.), a deep-rooted perennial, was introduced to North America from Russia in the early 1800s and has become a noxious weed in the north central United States and southern Canada (Best et al. 1980). Herbicides will not eradicate extensive infestations of leafy spurge, although they can be used to control this noxious weed (Fay 1992). Sheep readily graze leafy spurge (Johnston and Peake 1960, Landgraf et al. 1984, Olson et al. 1996). Sheep will not eradicate leafy spurge, but they may be a cost-effective method to control leafy spurge (Fay 1991, Williams et al. 1996). However, sheep ingest leafy

\footnotetext{
We thank Kathrin Olson-Rutz for reviewing the manuscript. This study was supported by the Montana Agricultural Experiment Station and the USDA CSREES

Published with approval of the Director, Montana Agricultural Experiment Station, as Journal No. J-2000-65.

Manuscript accepted 15 Feb. 01
}

Los herbivoros ingieren semillas de hierbas invasoras y pueden contribuir a su diseminación depositando semillas viables en áreas no infestadas. Algunas semillas maduras pasan a través del tracto gastrointestinal (TGI) de los rumiantes, pero los herbívoros consumen inflorecencias de especies invasivas desde la antesis hasta la dehiscencia. Colectamos semilla de "Eurasian leafy spurge" (Euphorbia esula L.) en tres estados de madurez (masa blanda, masa dura y madura). Utilizamos la semilla colectada en estas diferentes etapas de madurez para realizar un estudio con el objetivo de determinar los efectos de: 1) la tasa de paso a través del TGI de los borregos en la recuperación, germinabilidad y viabilidad de la semilla de "Leafy spruge" 2) el tiempo de residencia en el rumen del borrego en la germinabilidad y viabilidad y 3) la digestión de ácido pepsina, simulando el TGI bajo, en la germinabilidad y viabilidad de la semilla después de diferentes tiempos de residencia en el rumen En las heces se recuperó más semilla de los estados de madurez mas avanzados. El mayor número de semillas recuperadas solo represento el 3.9\% del total de semillas ingeridas. Pocas semillas se recuperaron después del cuarto día. La semilla del estado de masa blanda presente en las heces no germinarían y no fueron viables, mientras que la semilla madura y en estado de masa dura colectadas de las heces durante los primeros 4 días fueron viables. La pepsina tuvo un efecto ligero en el número de semillas maduras recuperadas, pero elimino la viabilidad de la semilla recuperada. La viabilidad de la semilla madura o de masa dura no tratada con pepsina declinó al aumentar el tiempo de residencia en el rumen. Así los manejadores deben estar concientes de que el ganado que ingiere semilla en las etapas de masa dura y madura puede estar dispersando semilla viable de malezas.

spurge seed and deposit viable seed in their manure (Olson et al. 1997), thus they should be managed accordingly (Olson 1999).

Mature seed of some invasive species will pass through the gastrointestinal (GI) tract of ruminants. Most mature leafy spurge seed are digested completely in the GI tract, and viability of mature seed that pass through the GI tract is usually reduced (Lacey et al. 1992, Olson et al. 1997). However, grazers consume flowerheads from anthesis to dehiscence. Ripening of leafy spurge seed can extend from early July until fall (Hanson and Rudd 1933, Best et al. 1980). Seed in earlier stages of development may also pass through the animal and some may remain viable. For example, we collected fecal pellets of sheep grazing leafy spurge-infested rangeland from late June until early August 
(Olson et al. 1997); the sheep passed viable seed over a 4 week period. However, we could not measure when or how many leafy spurge seed were ingested by sheep during that field study. Thus, we could not determine residence time, or the impact of digestion on seed viability.

For this study, we collected leafy spurge capsules (seed) at 3 stages of maturity (soft dough, hard dough, mature), and pulse-dosed sheep with a known amount of seed from these different stages. Our objectives were to determine 1) effects of rate of passage on seed recovery, germinabilty, and viability, 2) effects of residence time in the rumen on seed germinability and viability, and 3) effects of acid pepsin digestion, simulating the lower GI tract, on seed germinability and viability after different residence times in the rumen.

\section{Materials and Methods}

The leafy spurge fruit develops from a superior three-celled ovary (Messersmith et al. 1985). This capsule dehisces when ripe to distribute the seeds. Color differences in seedcoats have been used to determine seed maturity. Seed color changes from yellow, to yellow with brown tips, to brown, to grey brown, to mottled as seeds mature (Selleck et al. 1962, Wicks and Derscheid 1964). In contrast, Bakke (1936) suggested that immature seeds were grey and mature seeds were brown. Differences between age of maturity and seedcoat color may reflect that environments or biotypes differed at their collection sites. We distinguished immature from mature seeds using Selleck et al.'s (1962) and Wicks and Derscheid's (1964) approach. Yellow or partially yellow seeds were considered immature.

We collected capsules (seeds) of leafy spurge 3 times during the summer of 1994 (Lat $110^{\circ} 33^{\prime} \mathrm{W}$, Long $45^{\circ} 46^{\prime}$ ). The first collection (24 June 1994) coincided with the "soft dough" stage when seed is immature and most capsules were easily cut with a fingernail (Stage 1). The second collection (19 July 1994) coincided with the "hard dough" stage when most capsules are indurate and difficult to cut with a fingernail (Stage 2). For the third collection (10 August 1994), we harvested fully developed capsules and opened these capsules to remove mature seed (Stage 3 ). In the field, all leafy spurge seed does not mature at the same time (Olson et al. 1997). Some mature seed were present in collections of all 3 stages (Stage 1, 25\%;
Stage 2, 80\%; Stage 3, 100\%). We did not remove mature seeds from these first 2 stages because they would be available to grazing animals.

\section{Rate of Passage and Viability}

Capsules from Stages 1 and 2, and mature seeds from Stage 3 were fed to 5 rumen-cannulated ewes in separate trials. Each trial was separated by at least 14 days To ensure mastication of seed for each trial, 960 capsules $(2,880$ seed in Stage 3 ) were mixed with a small amount of barley and molasses in a feed bucket. Sheep had been exposed to the barleymolasses mix earlier. Most of the sheep consumed this mixture within a few hours, and all capsules were consumed within 24 hours. Before and during each trial ewes were fed grass hay ad libitum, and had access to water and a mineral block.

Sheep were in individual pens with plywood floors. All manure from each sheep was collected every 24 hours for 6 days after feeding the capsules (seeds). Each sheep averaged $95 \mathrm{~g}$ manure day ${ }^{-1}$ (dry weight). For each sheep, the 24 hour collection of manure was mixed, weighed while fresh, and divided into 9 subsamples. Three subsamples were selected randomly, and air-dried to determine moisture content. Three subsamples were selected randomly to recover seed. They were washed over sieves to remove excess organic material, and stored in a cool $\left(2^{\circ} \mathrm{C}\right)$, dark location to prevent seed maturation until samples from all 6 days had been collected. Then, leafy spurge seed and capsules were identified and removed from this material, categorized (immature, mature, capsule), counted, and stored under cool, dark conditions. The remaining 3 subsamples of each 24 hour collection were dried at $37^{\circ} \mathrm{C}$ and used in a different study (unpublished).

We determined our ability to recover leafy spurge seed from manure by adding 30 leafy spurge seeds to each of 5 manure samples from penned sheep with no access to leafy spurge. These spiked manure samples were washed according to procedures described above. All 30 seeds were recovered in each of the 5 manure samples.

To determine germinability, seeds were soaked in $10 \%(\mathrm{v} / \mathrm{v})$ chlorine bleach solution for 10 minutes to remove mold and bacteria, rinsed 3 times with distilled water, and then placed on moistened blotter paper. The number of recovered seed varied considerably. When more than 5 seeds were recovered, they were placed on moistened blotter paper in 5 petri plates. When more than 100 seeds were recov- ered, 20 seeds were tested on each of the 5 petri plates. Petri plates were placed in a shaded box in a greenhouse with day and night temperatures of $22^{\circ} \mathrm{C}$ and $16^{\circ} \mathrm{C}$, respectively. By allowing diffuse shortwave radiation but preventing direct shortwave radiation from reaching the seeds, the shaded box mimicked a plant canopy. Although alternating $30^{\circ} \mathrm{C} / 20^{\circ} \mathrm{C}$ maximizes germination of leafy spurge seed (Hanson and Rudd 1933), most leaf spurge seed germinates in early spring in the field (Selleck et al. 1962). In their study, most seeds germinated after 10 days of maximum air temperatures of $21^{\circ}$ or higher in late April, which is why we used the $22^{\circ}$ $\mathrm{C} / 16^{\circ} \mathrm{C}$ regimen. Photoperiod was approximately 16 hours day/ 8 hours night during this 28 June-20 July period. Distilled water was added as needed. Germinated seeds (radicles $>10 \mathrm{~mm}$ ) were counted every other day and removed.

After 3 weeks, seeds in these petri dishes were stratified in cold $\left(4^{\circ} \mathrm{C}\right)$, moist storage for 4 weeks. Germination of leafy spurge seed increases greatly when stratified for 4 weeks at $2-5^{\circ} \mathrm{C}$, preceding a constant $20^{\circ} \mathrm{C}$ treatment (Best et al. 1980). Petri dishes were returned to the greenhouse for 18 days, and germinability was tested as above. Photo period was approximately 14 hour day/10 hour night during this 21 August-8 September period. Germinability included seeds that germinated during the first test and those that germinated after stratification. Control seed which had not been fed and had been stored under cool, dark conditions were tested alongside recovered seed. We used 20 unfed seeds on each of 5 petri plates from each of the 3 stages.

Seeds that did not germinate could be viable, i.e. will germinate later, or be nonviable. After the second germinability test, seeds that did not germinate were tested for viability using a $0.1 \%$ unbuffered tetrazolium solution (Grabe 1970). Viability included seeds that tested positive with tetrazolium. Total viability included seeds that germinated and seeds that tested positive with tetrazolium.

\section{Residence Time, Acid Pepsin Digestion}

Effect of residence time in the rumen was tested by nylon bag technique with 5 rumen cannulated sheep. Sixteen nylon mesh bags $(5 \mathrm{~cm} \times 10 \mathrm{~cm}, 50 \mathrm{~mm}$ mesh) per stage, each containing 100 capsules (300 seed - Stage 3), were placed in the rumen of each sheep. Four of the 16 bags were removed at each of 4 retention times 
from each sheep: 12, 24, 48 and 72 hours. The bags were rinsed immediately with cold water to remove as much rumen fluid as possible, and then placed on paper towels until the bags were dry, but the capsules were still moist. Two bags of each set of 4 bags were air-dried for 48 hours. The other 2 were placed in a fresh, acid pepsin solution for 24 hours (Simao Neto and Jones 1987) to simulate conditions in the abomasum, then rinsed and dried as above. All seeds were tested for germinability and viability as described previously. Control seeds that were not placed in the rumen or treated with acid pepsin (controls) were tested for germinability and viability at the same time. For these tests, 3 subsamples of 30 seeds each were randomly selected from each nylon bag, including control seeds, and placed on 3 separate petri dishes. Mature and immature seeds were distinguished by seed color, and added together to determine total seed.

\section{Statistical Analyses}

We used the same sheep in the "rate of passage" and "residence time" studies. Each sheep was considered an experimental unit. The number of recovered leafy spurge seeds was estimated by determining the mean recovery from 3 of 9 subsamples, and then multiplying this mean by 9 , which was an estimate of each sheep each 24 hour period. Number of mature seed recovered, germinability $(\%)$, viability $(\%)$, and total viability (\%) were analyzed with repeated measures analysis of variance $(n=5$; SAS 1988). Seed stage was the between treatment effect; day (manure collection) within stage was the within treatment effect.

For the residence time-acid pepsin digestion trial, number of intact seed and total seed viability (\%) were analyzed with repeated measures analysis of variance. Again, each sheep was an experimental unit. Seed stage was the between treatment effect; when the nylon bags were removed $(0,12,24,48,72$ hours) from the rumens of the sheep was the within treatment effect. Because there were only 5 experimental units (sheep), P-values less than 0.10 are presented (Gill 1981).

\section{Results}

\section{Rate of Passage and Viability}

The number of mature seed recovered over the 5 day period varied by stage (day by stage, $\mathrm{P}=0.02$; Table 1 ), but consistently declined with time (day, $\mathrm{P}=0.02$ ). Number of mature seed recovered was greatest for seed from Stage 3, intermediate for seed from Stage 2, and least for seed from Stage 1 (stage; $\mathrm{P}=0.002$ ). However, for any 1 day, the greatest number of mature seed recovered (Stage 3, day 2 ) only represented $2.4 \%$ of the number of seed consumed. Summed across the 5 day collection period, recovery of mature seed was $0.2 \%$ for Stage 1, $1.5 \%$ for Stage 2, and $3.8 \%$ for Stage 3. Few seeds were recovered after day 4 .

Immature seed did not germinate because it did not contain a viable embryo. Germinability of mature seed collected over the 5 day varied by stage (day by stage, $\mathrm{P}=0.01$; Table 1 ). The relatively high germinability of Stage 2 seed from day 4 reflected germinability of seed from only 1 of the 5 sheep (data not shown). Overall, germinability was greatest for seed from Stage 3, intermediate for seed from Stage 2, and 0 for seed from Stage 1 (stage; $\mathrm{P}=0.07$ ).

Viability was greatest for seed from Stage 3, intermediate for seed from Stage 2, and 0 for seed from Stage 1 (stage, $\mathrm{P}=$ 0.09; Table 1). No viable seed were passed after day 2. Overall, total viability (germinability + viability) was greatest for seed from Stage 3, intermediate for seed from Stage 2, and 0 for seed from Stage 1 (stage; $\mathrm{P}=0.006$ ).

\section{Residence Time, Acid Pepsin Digestion}

We could not control residence time of seed in the GI tract in the rate of passage trial. In this trial, we controlled residence time of seed in the rumen, with and without acid pepsin digestion. The number of total seed recovered, which included mature seed, immature seed, and seed within capsules, was lowest from Stage 1 $(166 \pm 3)$, intermediate from Stage 2 (226 $\pm 2)$, and greatest from Stage $3(300 \pm 0$; stage, $\mathrm{P}<0.0001)$. Overall, the total number of seed was not affected by residence time in the rumen (hour by stage; $\mathrm{P}=$ 0.36 ).

Viability of control seed, seed that was not placed into the rumen, was 65,75 , and $84 \%$ for Stages $1-3$, respectively.

Table 1. The number of immature and mature seed recovered $($ No), and germinability $(\%)$, viability $(\%)$, and total viability $(\%$, total viability $=$ germinability + viability) of mature seed from Stages 1-3 recovered over a 5 day collection period. Each sheep received approximately 960 capsules (or 2,880 seed) of soft dough (Stage 1), hard dough (Stage 2), and mature seed (Stage 3). Some mature seed were present in seed fed for all 3 stages (Stage 1, 25\%; Stage 2, 80\%, Stage 3, 100\%). Immature seed (yellow seed coat) never germinated and was never viable. Means plus or minus 1 SE $(\mathbf{n}=5$ sheep).

\begin{tabular}{|c|c|c|c|c|c|c|}
\hline \multirow[b]{2}{*}{ Stage } & \multirow[b]{2}{*}{$\overline{\text { Day }}$} & \multicolumn{5}{|c|}{ Seed recovered } \\
\hline & & Immature seed & Mature seed & Germinability & Viability & Total Viability \\
\hline 1 & $\begin{array}{l}1 \\
2 \\
3 \\
4 \\
5\end{array}$ & $\begin{array}{c}7.2 \pm 3.2 \\
1.2 \pm 1.0 \\
1.8 \pm 1.8 \\
0 \\
0\end{array}$ & $\begin{array}{c}2.4 \pm 10.6 \\
1.2 \pm 6.0 \\
0.6 \pm 1.8 \\
0 \\
0.6 \pm 0.6\end{array}$ & $\begin{array}{l}0.0 \\
0.0 \\
0.0 \\
0.0 \\
0.0\end{array}$ & $\begin{array}{l}0.0 \\
0.0 \\
0.0 \\
0.0 \\
0.0\end{array}$ & $\begin{array}{l}0.0 \\
0.0 \\
0.0 \\
0.0 \\
0.0\end{array}$ \\
\hline 2 & $\begin{array}{l}1 \\
2 \\
3 \\
4 \\
5\end{array}$ & $\begin{array}{c}3.6 \pm 8.7 \\
1.2 \pm 3.1 \\
0 \\
0.6 \pm 1.4 \\
0\end{array}$ & $\begin{array}{c}15.5 \pm 10.7 \\
6.9 \pm 6.0 \\
3.0 \pm 1.8 \\
2.4 \pm 1.2 \\
0\end{array}$ & $\begin{array}{c}19.4 \pm 8.9 \\
0.0 \\
0.0 \\
10.0 \pm 6.1 \\
0.0\end{array}$ & $\begin{array}{c}21.9 \pm 15.1 \\
0.0 \\
0.0 \\
0.0 \\
0.0\end{array}$ & $\begin{array}{c}41.4 \pm 12.0 \\
0.0 \\
0.0 \\
10.0 \pm 6.1 \\
0.0\end{array}$ \\
\hline 3 & $\begin{array}{l}1 \\
2 \\
3 \\
4 \\
5\end{array}$ & $\begin{array}{l}0 \\
0 \\
0 \\
0 \\
0\end{array}$ & $\begin{array}{c}24.3 \pm 12.5 \\
71.1 \pm 7.0 \\
9.8 \pm 2.0 \\
2.8 \pm 1.5 \\
0.7 \pm 0.7\end{array}$ & $\begin{array}{c}31.7 \pm 10.4 \\
24.4 \pm 4.1 \\
0.0 \\
0.0 \\
0.0\end{array}$ & $\begin{array}{c}49.4 \pm 17.8 \\
11.6 \pm 1.2 \\
0.0 \\
0.0 \\
0.0\end{array}$ & $\begin{array}{c}81.3 \pm 14.0 \\
36.0 \pm 5.0 \\
0.0 \\
0.0 \\
0.0\end{array}$ \\
\hline
\end{tabular}




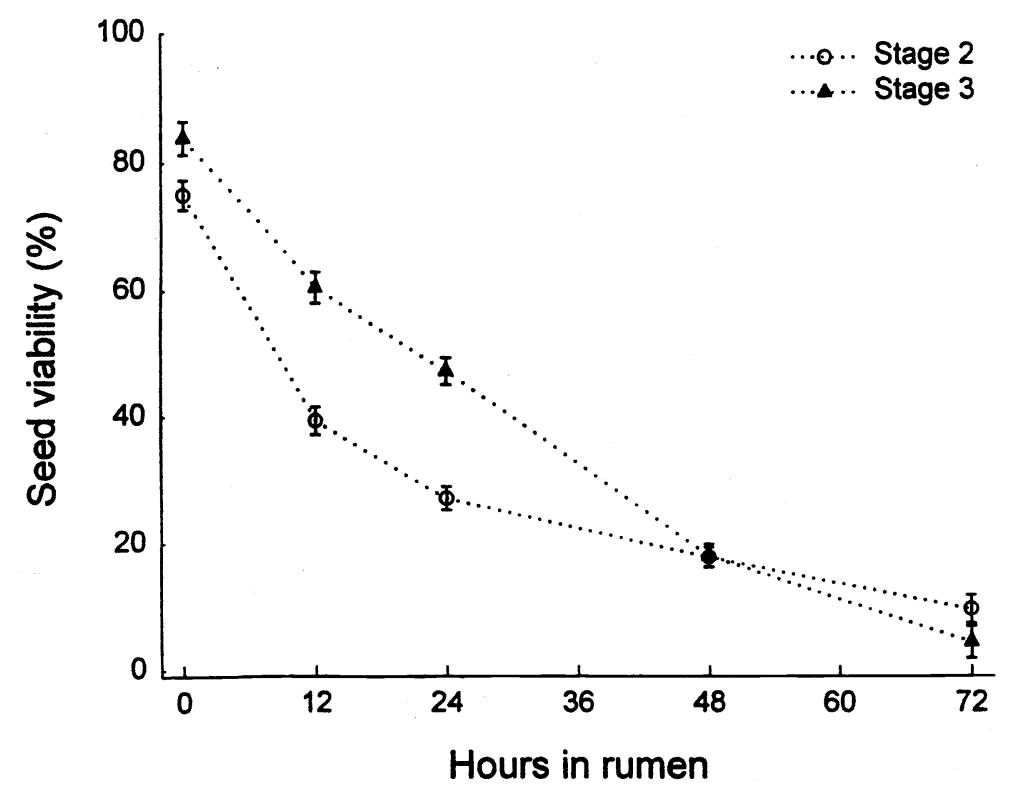

Fig. 1. Effect of residence time (h) in sheep rumen on total viability (\%) of mature leafy spurge seed from Stages 2 and 3. Seed from Stage 1 were not viable after exposure to the rumen. Some mature seed were present in collections of all 3 stages (Stage 1, 25\%; Stage 2, $80 \%$, Stage 3, 100\%). Total viability of seed which had not been placed in the rumen $(0 \mathrm{~h})$ was 65,75 , and $84 \%$ for Stages $1-3$, respectively. Means plus or minus 1 SE $(n=5$ sheep).

Viability of pepsin treated seed from all 3 stages was 0 , thus this treatment was removed from the statistical model. Viability of non-pepsin treated seed varied with stage and time in the rumen (Fig. 1; hour by stage; $\mathrm{P}=0.0001)$. Other than control seed ( 0 hour), viability of seed from Stage 1 was 0 , whereas viability of seed from Stages 2 and 3 declined with time spent in the rumen.

\section{Discussion}

\section{Rate of Passage and Viability}

Some mature seed were present in collections of all 3 stages (Stage 1, 25\%; Stage 2, $80 \%$, Stage 3,100\%). On most days, immature and mature seed were recovered in the same proportions that they were fed, indicating immature seeds were resistant to digestion, at least structurally. For legumes, soft seed is destroyed by digestion whereas hard seed is relatively resistant to digestion (Simao Neto and Jones 1987, Gardener et al. 1993).

The greatest number of seed recovered (Stage 3) only represented about $4 \%$ of the number of seed consumed. In another study with leafy spurge, $18 \%$ of seed fed to sheep and goats was recovered in the manure of both animal species (Lacey et al. 1992). With a different invasive weed Centaurea maculosa, $4 \%$ of the seed dosed was recovered in 1 trial with ewes, whereas $17 \%$ of the seed dosed was recovered in a second trial with rams (Wallander et al. 1995). Experimental protocol differed slightly between those trials; presumably these differences were not related to gender.

Few seeds were recovered after day 4. In related studies, most weed seeds pass within 4-5 days (Piggin 1978, Lacey et al. 1992, Wallander et al. 1995). Thus, animals grazing weed infested areas with mature seed should not be moved to uninfested areas for at least 4-5 days to prevent dispersal of viable seed.

Seed recovered from Stage 1 did not germinate and was not viable, even though about $25 \%$ of the seed was mature. Apparently, seed of leafy spurge at this early stage of development will not survive the GI tract of sheep. Some seed in the hard dough and mature stages (Stages $2,3)$ germinated and remained viable, ingestion.

Only seed recovered within 1 (Stage 2) to 2 days (Stage 3) would germinate or was viable, except for some Stage 2 seed recovered 4 days after ingestion. However, these seeds were recovered from the manure of only 1 of the 5 sheep. Possibly, seed had been entrapped within the GI tract, and were released all at once.

No viable seed were recovered after day especially when passed within 2 days of
4, which may reflect the effect of the GI tract on seed passage and seed viability. Leafy spurge seed imbibes water quickly, beginning within 6 hours of exposure and continuing for an additional 42 hours (Selleck et al. 1962). Germinability was equal to (Stage 2) or less than (Stage 3) viability in seed recovered from the first day, whereas germinability was greater than viability on seed recovered on day 2 from Stage 3. This may reflect that germinability was enhanced by short-term residence time in the rumen. Lacey et al. (1992) found that leafy spurge seed did not germinate after 1 day in the rumen of sheep; seed recovered after 4 days were not viable. In a related study, viability of Centaurea maculosa seed was minimal after 5 days in the GI tract of sheep, but retained viability up to 10 days (end of trial) in mule deer (Wallander et al. 1995). Blackshaw and Rode (1991) also found that weed seeds survive for short periods of time in the rumen but viability drops off rapidly. The effect of different exposure periods in the rumen vary among different weed species (Harmon and Keim 1934), diets (Blackshaw and Rode 1991), and ruminants (Harmon and Keim 1934, Simao Neto et al. 1987).

\section{Residence Time, Acid Pepsin Digestion}

Control seed not placed in the rumen from Stages 1-3 were 65, 75, and 84\% viable, respectively. Others have found viability of leafy spurge seed ranging from $51 \%$ to $90 \%$ (Hanson and Rudd 1933, Bakke 1936, Bowes and Thomas 1978, Lacey et al. 1992).

The survival of seed passing through the GI tract is influenced by residence time in the GI tract and exposure to digestive enzymes. Nylon bags placed in the rumen, such as in this study, can be used to simulate different residence times in the rumen but do not expose seeds to digestive secretions in the lower GI tract, which is why we included the pepsin treatment. In addition, using seed in nylon bags does not include the effects of mastication during prehension or rumination on the seed coat, which may be a key factor that influences digestion, disintegration, and viability of seed. This would explain why more seed were recovered in this trial compared with the "rate of passage" trial where seed were ingested by the sheep and passed through their entire GI tract.

Our pepsin treatment may have been excessive; none of the pepsin-treated seed were viable. In another nylon bag trial, a 24 hour pepsin treatment greatly reduced 
viability of seed from signal grass Bracharia decumbens, but had much less of an effect on carpet grass Axonopus affinis (Simao Neto and Jones 1987). Our 24 hour pepsin treatment exceeded the 10-12 hours where seed is normally exposed to acid pepsin in the GI tract (Ocumpaugh and Swakon 1993), which may explain why our seed were no longer viable following this treatment. In the seed recovery-seed viability part of our study and in related studies, viability of seed passing through the GI tract is greatly reduced but not completely eliminated (Heady 1954, Lacey et al. 1992, Wallander et al. 1995 Olson et al. 1997). In the lower GI tract, some seed apparently escape gastric secretions in the abomasum (pepsin, hydrochloric acid) and small intestine (trypsin, chymotrypsin), possibly by passing through the system quickly.

Even without the pepsin treatment, soft dough seed were not viable, presumably because the seed was too soft and could not resist disintegration or microbial digestion in the rumen. Most soft seeds disintegrate after 2 days in the GI tract (Gardener et al. 1993). Viability of seed from the hard dough and mature stages which was not exposed to pepsin declined with time spent in the rumen, indicating that the seed coat softens with time and becomes susceptible to microbial digestion. Germinability (viability) of ingested seed typically declines with greater digestion times (Ocumpaugh and Swakon 1993, Ocumpaugh et al. 1995).

\section{Conclusion}

Many mature seed from the hard dough and mature stages were digested in the GI tract, but some of the recovered seed were viable. Thus, managers should be aware that livestock ingesting hard dough leafy spurge seed in late June and early July may be dispersing viable seed. With one exception, all viable seed passed within 2 days of ingestion. Because of this exception and results from another study (Lacey et al. 1992), livestock grazing leafy spurge should not be moved until all possible viable leafy spurge seed has passed, conservatively 4-5 days. Sheep will graze leafy spurge (Olson 1999); however, they need to be managed in a manner that will help control the problem, not contribute to it.

\section{Literature Cited}

Bakke, A.L. 1936. Leafy spurge Euphorbia esula L. Iowa Agr. Exp. Stat. Res. Bull. 198:209-246.

Best, K.F., G.G. Bowes, A.G. Thomas and M.G. Maw. 1980. The biology of Canadian weeds. 39. Euphorbia esula L. Can. J. Plant Sci. 60:651-663.

Blackshaw, R.E. and L.M. Rode. 1991. Effect of ensiling and rumen digestion by cattle on weed seed viability. Weed Sci. 39:104-108.

Bowes, G.G. and A.G. Thomas. 1978. Longevity of leafy spurge seeds in the soil following various control programs. J. Range Manage. 31:137-140.

Fay, P.K. 1991. Controlling leafy spurge with grazing animals. p. 193-199. In: L.F. James, J.O. Evans, M.H. Ralphs and R.D. Child (eds), Noxious range weeds. Westview Press, Boulder, Colo.

Fay, P.K. 1992. The role of herbicides in weed management. Western Wildlands, Summer Issue. p. 24-26.

Gardener, C.J., J.G. McIvor and A. Jansen. 1993. Passage of legume and grass seeds through the digestive tract of cattle and their survival in faeces. J. Appl. Ecol. 30:63-74.

Gill, J.L. 1981. Evolution of statistical design and analysis of experiments. J. Dairy Sci. 64:1494-1519.

Grabe, D.F. 1970. Tetrazolium handbook. Assoc. Official Seed Analysts. Omaha, Nebreaska. $62 \mathrm{p}$.

Hanson, H.C. and E. Rudd. 1933. Leafy spurge life history and habits. North Dakota Agr. Coll. Agr. Exp. Stn. Bull. No. 266. 24 pp. Fargo, N.D.

Harmon, G.W. and F.D. Keim. 1934. The percentage and viability of weed seeds recovered in the feces of farm animals and their longevity when buried in feces. J. Amer. Soc. Agron. 26:762-767.

Heady, H.F. 1954. Viable seed recovered from fecal pellet of sheep and deer. J. Range Manage. 7:259-261.

Johnston, A. and R.W. Peake. 1960. Effect of selective grazing by sheep on the control of leafy spurge (Euphorbia esula L.). J. Range Manage. 13:192-195.

Lacey, J.R., R.T. Wallander, and K.M. Olson-Rutz. 1992. Recovery, germinability and viability of leafy spurge (Euphorbia esula) seeds ingested by sheep and goats. Weed Tech. 6:599-602.

Landgraf, B.K., Fay, P.K. and K.M. Havstad. 1984. Utilization of leafy spurge (Euphorbia esula) by sheep. Weed Sci. 32:348-352.

Messersmith, C.G., R.G. Lym, and D.S. Galitz. 1985. Biology of leafy spurge. In A.K. Watson (ed), Leafy spurge. Weed Science Soc. Amer. Champaign, Ill.
Ocumpaugh, W.R. and D.H.D. Swakon. 1993. Simulating grass seed passage through the digestive system of cattle: a laboratory technique. Crop Sci. 33:1084-1090.

Ocumpaugh, W.R., C.R. Tischler, and L.S. Valle. 1995. Post-harvest dormancy effects on kleingrass germination following simulated digestion by cattle. Crop Sci. 35:260-263.

Olson, B.E. 1999. Grazing and weeds. p. 85-96. In: R.L. Sheley and J.K. Petroff (eds), Biology and management of noxious rangeland weeds. Oregon State University Press, Corvallis, Ore.

Olson, B.E., R.T. Wallander and R.W. Kott. 1997. Recovery of leafy spurge seed from sheep. J. Range Manage. 50:10-15.

Olson, B.E., R.T. Wallander, V.M. Thomas and R.W. Kott. 1996. Effect of previous experience on sheep grazing leafy spurge. Appl. Anim. Behav. Sci. 50:161-176.

Piggin, C.M. 1978. Dispersal of Echium plantagineum L. by sheep. Weed Res. 18:155-160.

SAS. 1988. Statistical analysis system. SAS Institute Inc. Raleigh, N.C.

Selleck, G.W., R.T. Coupland, and C. Frankton. 1962. Leafy spurge in Saskatchewan. Ecol. Mono. 32:1-29.

Simao Neto, S. and R.M. Jones. 1987. Recovery of pasture seed ingested by ruminants. 2. Digestion of seed in sacco and in vitro. Aust. J. Exp. Agr. 27:247-251.

Simao Neto, S., R.M. Jones, and D. Ratcliff. 1987. Recovery of pasture seed ingested by ruminants. 1. Seed of six tropical pasture species fed to cattle, sheep and goats. Aust. J. Exp. Agr. 27:239-246.

Wallander, R.T., B.E. Olson, and J.R. Lacey. 1995. Spotted knapweed seed viability after passing through sheep and mule deer. J. Range Manage. 48:145-149.

Wicks, G.A. and L.A. Derscheid. 1964. Leafy spurge seed maturation. Weeds 12:175-176.

Williams, K.E., J.R. Lacey, and B.E. Olson. 1996. Economic feasibility of grazing sheep on leafy spurge-infested rangelands in Montana. J. Range Manage. 49:372-374. 